\title{
DISCUSSION ON THE ORIGIN OF GLACIAL DRIFTS
}

\author{
held at the Department of Geography, Cambridge, on 2 December 1949
}

\section{Chairman : Mr. J. M. WORDIE}

Professor S. E. Hollingworth (University College, London): To be introduced as a champion of orthodoxy is not perhaps entirely a happy situation. It could imply that one had in the main to reiterate already well-known views. In his persistent and resolute challenge to orthodoxy, Mr. Carruthers has brought forward a mass of interesting material superlatively prepared and illustrated, and he has more to show us to-night. I would suggest that he has fully justified a thorough re-examination of the orthodox view, rather than a reiteration.

His interpretation of an upward sequence of drift deposits such as boulder clay, banded clays, sands and overlying boulder clay by bottom melting, has led him to reject the multi-glaciation view of the origin of British drifts. Good critical sections demonstrating multi-glaciation are rare, even in the widespread outer zone where deposition was dominant in continental Europe and North America at the time of the Pleistocene ice sheets. There, nevertheless, multi-glaciation meets with general acceptance. In Britain the topography and the glacial conditions generally are less favourable to the preservation of areas where inter-glacial deposits might have been formed and conditions for dissection are far from favourable. The rare "Kirklington" and "Kelsey" have been preserved, and their acceptance as evidence of inter-glacial beds has survived intensive attack in the past. Their rarity should give them a special value rather than lead to their being regarded as suspect and as a phenomenon to be explained away.

The mode of origin of the drifts is critical to all such interpretations. I regard myself here not necessarily as a supporter of orthodoxy, but as one who is prepared to re-examine that view.

One must be very selective in the time available. The origin of the banded or laminated clays has been discussed in print a good deal already as, for instance, at the meeting of the Geological Society reported in the Quarterly Fournal of the Geological Society of London, Vol. 96, Part 2, I940, p. 249-69. We might therefore select the mode of deposition of boulder clay for consideration. There is probably too much variation in the physiographic control and in the conditions of accumulation to justify the application of an explanation which fits one area to another. Thus the mode of deposition of the boulder clay of the inter-montane areas of north-west Britain, for example those of the midland valley of Scotland or those of north-east Ireland, or of the Solway Basin, does not necessarily fit East Anglia, or even the area east of the Pennines.

I propose to select the Vale of Eden for consideration. Is the boulder clay there a true moraine formed by the sub-glacial deposition of englacial material by ice in movement, or is it material that was englacial up to the time of the final melting? Goodchild thought the latter. He was, in fact, a pioneer of the theory of rapid decay of ice sheets and stagnant ice. Now the boulder clay occurs in highly characteristic form, and constitutes one of the finest examples of drumlin topography. The typical streamline flow form of the drumlins clearly indicates a direction of movement of the basal layers of the ice sheets. These demonstrate that the moulding movement must have taken place at, or near, the maximum development of the last ice sheet.*

Building up by some process of plastering of englacial material on to the sub-glacial surface seems unavoidable. The mechanics of this is less certain. I think there was some sort of "straining" or sieving action whereby highly mobile ice migrated from the regions of maximum pressure by recrystallization, leaving "included" solid debris behind. I have suggested that such a process operated in the case of deformation of anhydrite and its redistribution, leaving behind silty impurities. $†$

* Hollingworth, S. E. Quarterly Fournal Geological Society of London, Vol. 87, Part 2, 1931, p. 281-359.

$\dagger$ Hollingworth, S. E. Abstracts, Proceedings Geological Society of London, No. 1452, 17 June 1949, p. 100. 
The classic work of Dr. G. Slater on the structure of the disturbed drift deposits of the Ipswich area is relevant. Here large masses of Tertiary and Drift formations have been caught up in the ice sheet, carried a mile or two, and then plastered on to obstacles with steep thrust plane junctions and sigmoidal curve forms. These sections are amongst the clearest examples of fossil glacier tectonics. The absence of distortion by compaction in a vertical direction, indicates that the proportion of ice to englacial matter was quite small. One might refer here to the absence of any vertical distortion in the contorted banded clays previously described by $\mathrm{Mr}$. Carruthers, in view of their interpretation as original inter-glacial banded dirts with presumably, say, 70-80 per cent of ice.

Was Goodchild right in claiming a rapid decay in situ for his ice sheets? There can be little doubt that his intuition has largely been substantiated by later detailed work. This indicates that climatic change produced a dying ice mass bereft of its sources of supply. It became an accumulation of cold, quite out of phase with its external environment. Summer ablation over almost the whole surface produced a vertical lowering as is demonstrated from the relation of the ice fronts to topography that derives from a systematic mapping of frontal phenomena.

Such conditions resemble those of stagnant ice, so well described by Dr. Carl Mannerfelt in the Scandinavian mountains, and by Dr. Sigurd Hansen in Denmark. Surface lowering of the order of several metres a year has been inferred by these investigators. Now the only available source of heat for bottom melting is presumably from below, and that can be estimated to produce melting of the order of one centimetre a year. It is interesting to note in this case a ratio of summer to winter melting that appears to be of the same order as the ratio of the summer to winter meltwater outflow from alpine glaciers. It would appear that the conditions favourable for bottom melting to make any important contribution to glacial deposits would be those in which there has been a slow disappearance of the ice with annual loss from all causes only slightly in excess of nourishment. This would probably imply continuance of active forward movement rather than stagnation. The conditions inferred from a study of the waning of the last ice sheet in the Vale of Eden, and other areas, appear to be the most unfavourable to the operation of bottom melt as a significant factor in glacial deposition.

Mr. Carruthers regards the presence of lenses of Till in his laminated clays as a highly critical point indicative of undermelting. It is worth while to refer to Hansen's observation that in the Danish clays such lenses are invariably associated with the "spring melt" laminae. His interpretation is that thawed boulder clay sludged on to the frozen surface of lakes during the spring thaw and subsequently sank slowly to the botton as the bouyancy of the supporting ice decreased.

We need still more facts, more studies of the structure of glaciers, and investigation of presentday sedimentation in lakes fed by melt water in high latitudes. Too much weight has been placed upon Chamberlin's few observations of the banded dirts of the Greenland glaciers. We may hope that this discussion will do a little to stimulate such future studies.

Mr. R. G. CARRUthers: This renewal of trouble over the origin of our native Drifts-trouble quiescent for well-nigh a century-is due to a fundamental error in the older reasoning. Plain though the signs are, in both ancient and modern glaciations, it was forgotten that decaying ice sheets melt underneath, as well as on top, a vital circumstance since englacial detritus, on any theory the ultimate source of these Drifts, abounds in the lower ice. To my surprise Professor Hollingworth, on purely theoretical grounds, continues his disbelief in any such undermelt, or would at any rate concede very little of the kind. Frankly, I distrust his data, remembering those physicists who hold that the weight of the ice would suffice, let alone the heat of the earth. Be that as it may, I prefer direct factual observation as used in many and diverse forms in my two previous papers.* Is it either wise or right to ignore these things?

* (a) On northern Glacial Drifts. Quarterly Journal Geological Society London, Vol. 95, Part 3, 1939, p. 304-5 : also Discussion on above. Ibid., Vol. 96, Part 2, p. 266.

(b) The secret of the Glacial Drifts. Proceedings Yorkshire Geological Society, Vol. 27, Part 2, 1946, p. 46. 
My purpose to-night is to show that undermelt attacked Pleistocene ice sheets even as it does those of to-day. What happened then is doubtless happening now, although I fancy it is only through the study of our Drifts at home that such knowledge can be obtained, for everything occurs far under the ice, where on release pressures remain unchanged.

I gather that undermelting may be allowed for Basement Till. How indeed can the evidence be read otherwise? But what about those trouble-makers the "Stratified Drifts," about which so little was said? They are the core of our problem; round their interpretation the whole controversy turns. The conventional view always is that they are of extra-glacial origin, a sign of retreat, and that any "Upper Till" deposits therein, if far-spread and distinctive, signify re-advance. Now since they are supposed to be lacustrine, or at least water-laid, and to come from washes of englacial detritus, it is as well to examine for comparative purposes unquestioned sediments of that kind, even though of post-glacial date. Here one finds that all of the five examples available (four freshwater, one estuarine) showed that:

(I) the bedding is coarse, generally vague, often barely discernible,

(2) shells are usual, organic debris universal,

(3) there are no slumps, folds or other signs of contemporary movement, even on depositional slopes of $8^{\circ}$.

That, with at times some good grading, and, amongst the thicker sands, current-bedding, is about all there is to be seen.

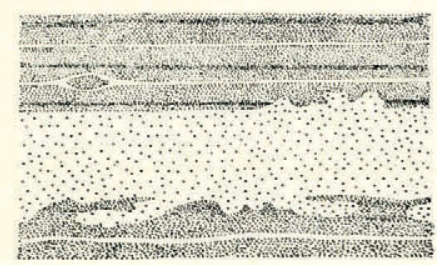

(a)

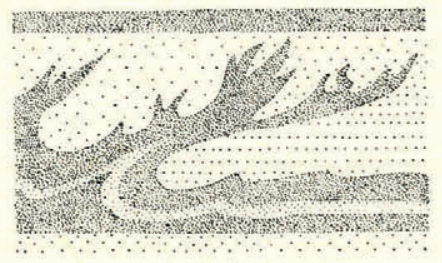

(b)

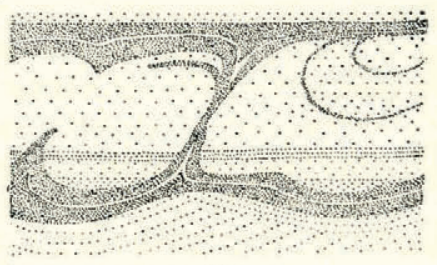

(c)

Fig. I. Some bedding arrangements in "Stratified Drifts":

(a) Shear clay with interbanded sand. (b) and (c) Suspension structures due to roof falls All about one quarter natural size

Consider now the glacial laminated clays, those amongst the "Stratified Drifts." These shearclays, as I now call them ("pressed melts" is not a good term) are notable for:

(I) flow structure everywhere without exception, showing itself in a machine-like lineation, often astonishingly minute, without rhythm and with an equal disposition round all foreign bodies large or small,

(2) complete absence of indigenous shells or organic matter,

(3) frequent crumpled layers between flat-lying, flowed clays,

(4) intact current bedding amongst the many sand partings,

(5) a common erosion by these sands without sign of injection. This eats into (i.e. is of later date than) the floor, and at times even the roof of flowed clay as shown in Fig. I (a),

(6) here and there are lines of "inverted ripple marks," burrowing into the clay beneath, but leaving the upper surface of the sand flat or but very gently raised, as if there had been a resistant cover forbidding a normal build-up,

(7) good grading in the silt zone, though little in the main shear-clay assemblages below.

And now compare all this with the first group, the truly lacustrine, water-laid sediments. The contrast could hardly be greater; true, both are clays and in part may show grading, with current bedding in the sands, but there all further resemblance ends. However that is not the last of the 
story by any means, for in the covering silts, where sand is in the ascendant, such bands of shearclay as are left assume extraordinary forms quite unknown in other sediments. In these "suspension structures," as I call them, the clay stripes may tail off upwards (Fig. I $(b)$ ) in groups of steeply inclined streamers ("flames"), or again there may be a continuous roof and floor with clay connectors here and there and sand-filled compartments between, wherein the bedding, though usually tumultuous, can at times run horizontally from one compartment to the next (Fig. I (c)). Finally, note the under-contacts of the widespread sheets of "Upper Till" quite often seen in the covering sands. All of these are either sharp-cut and flat, or have loops, wisps, lenses and fragments of the Till connected or not with the main body above but not disturbing the current-bedded sand which seems to have gathered quietly around them. Solifluxion effects apart, the Till itself has neither disturbed nor incorporated what lies below. These appearances are not local, they are general. I have never seen an "Upper Till" contact without them. They are of high interest, and no serious enquirer can afford to ignore them.

Putting all this together, how is it possible to maintain any longer that these "Stratified Drifts" are normal, extra-glacial sediments with the "Upper Tills" marking renewed glaciation? Why attempt it indeed, when an unforced, natural explanation lies to hand? All the oddities listed above can readily be obtained by continuing the undermelt, already admitted for the Basement Till, through the "banded dirts" so often seen in the higher englacial detritus of modern ice sheets. Dirts which, as Chamberlin long ago saw, abound in flow structure - that is to say tectonic flowfor they represent the sheared-off tops of the underlying "bottom dirt," the source of till. The sand partings obviously come from the melt-out of intercalated ice bands - that is why their erosions occurred after the flow of the clays. And when, higher up, these ice partings increased and and so, on melting, provided a greater depth of water, opportunity arose for those strange "suspension structures," which at first looked so puzzling. They are falls from clay roofs released during the undermelt, some while part was still frozen in, others (the "flames") delayed till the very last moment. Much of their diversity is due to varied speed in melting, depth and rate of flow of the water, accumulation of sand and so on. In visualizing past conditions, nothing can be more instructive.

A word about the tills so frequently associated with these "Stratified Drifts." The thin beds and lenses intercalated in the main shear-clays represent the incomplete disintegration of shearedoff basement material. Both their content and their disposition make this clear enough. But the wide-spread, highly individualized sheets so often seen in the topmost sands I now look on as "overriders" from glaciers tributary to the main sheet. They are superimposed, the whole forming but a single ice mass. Hence their remarkable under-contacts, in their way as vivid a proof of roof falls as are the "suspension structures" amongst the higher shear-clays.

Much else I can only mention briefly. For instance that the melting of certain shear-clay bands was preferential, insinuating itself along selected layers and so leading, in the silt-zone, to falls incompletely thawed out. Or again, less often, that re-freezing could occur. Yet again that crumpling may affect either frozen clay released intact or material fully melted. All this can wait, but the main conclusion that our English Drifts are wholly sub-glacial and derive from the undermelt of a single, complex ice-sheet is inevitable. How else explain what I have shown you? No! Pleistocene history, so long a stumbling block in Britain, as opposed to its clarity, or relative clarity, abroad, can now be re-written. And it will be a very different story to that hitherto current.

Mr. W. V. Lewis (Department of Geography, Cambridge University): Whilst having to disagree with many of Mr. Carruthers's conclusions may I say at once how grateful I am for the spirited manner in which he has presented his most original ideas. Mr. Carruthers is forcing us to think again about many of our long held and often poorly substantiated opinions, and nothing but good can come from such a re-examination. The interpretations which he presents in such a 
startling manner should make us far more discerning in our field observations, and more discriminating in the deductions we draw from them.

Mr. Carruthers called attention to what appeared in cliff sections as lenticular inclusions of laminated sands lying at the base of masses of drift. He gave this as evidence of bottom melt, but I should have thought a more likely explanation is that they were sands and gravels deposited in melt-water tunnels beneath the ice-local survivals of a form of sub-glacial esker. Mr. Carruthers too, overdrew, I thought, the picture of the rarity of glacial lake deposits at the edge of an ice sheet. I agree wholly with Mr. Carruthers's injunction to go out into the field and observe for ourselves.

The ice sheet with which I am slightly familiar and which is of the type that once spread over the scene of Mr. Carruthers's notable observations, is the northern border of Vatnajökull. ${ }^{1}$ This has several lakes at its margins. Ice sheets which block the normal land drainage must constantly give rise to marginal lakes in which much fine material cannot fail to be deposited. In one of these lakes at Kverkfjöll we noted many inclusions of Till in what were undoubted deltaic deposits of a large glacial-dammed lake on the site of a smaller one still surviving. Below one of these inclusions the bedded deposits had been rucked up as if they had checked the landward motion of an iceberg as it stranded. We therefore had little doubt that most of the coarse inclusions came from stranded icebergs, so I am sorry that Mr. Carruthers was somewhat scornful of this view.

We are certainly far from understanding the way in which glaciers deposit their material. Some comparatively short glaciers such as Skauthöe in Jotunheimen, and Smedbotn in Rondane, have large moraines in front of them rather like those at the head of Langdale in the Lake District. Other larger glaciers are almost covered with moraines for a great part of their length, such as that emerging from the composite north-west cirque of Snaefell in east Iceland. ${ }^{2}$ Still others, such as Heillstuggubreein ${ }^{3}$ in Jotunheimen, which appear quite active, are almost bare of material except perhaps where moraines have added their quota of debris. Any objective consideration, at least of temperate glaciers, points to the importance of the concentration of material on the surface as a result of surface melting. Ablation measurements confirm this impression of active surface melt. On Vatnajökull a single rain storm can melt away one foot of the surface of the ice cap, and in Norway during the hot summer of 1947 the ends of many glaciers were down-melting at the rate of three to five metres a month. This contrasts markedly with the centimetre or less of bottom melt a year, due to heat from the interior of the earth. The problem of supplying heat for any other form of substantial bottom melting seems insurmountable. The regime of alpine glacier-fed streams follows closely the rhythm of surface melting on the glaciers. This, as Professor Hollingworth has stated, points strongly to the fact that surface melting far outweighs all other forms of melting.

An examination of the margins of glaciers which are melting rapidly to-day shows one very important feature which Mr. Carruthers has rightly stressed-the presence of overthrusts or glide planes, often with included material. Most interesting patterns produced by glide planes can be seen from any high point overlooking the western side of Brúarjökull, a great northern lobe of Vatnajökull. These patterns show up clearly in the distance because the dirt and debris brought up along the glide planes becomes concentrated on the surface of the glacier by down-melting. These lines sweep in great curved arcs round a projecting nunatak. Elsewhere they form lines on the surface of the ice running parallel with the ice margin. Where the ice ends as a great cliff the arrangement of these dirt bands can be seen in section. ${ }^{4}$ Quite broad-looking dirt bands rise to the surface of the glacier in great sweeping arcs concave upwards. One must not be misled, however, by the apparent thickness of the dirt bands, because, owing to the dirt being washed down the cliff face, the latter is discoloured over a far wider zone than that of the original dirt which may be confined to a centimetre or less. Judging from the examples I have noted 95 per cent or more of the total thickness consists of ice. 
The lobe of Eyjabakkajökull further to the east, being nearer to the end of the glacier, is much more debris-charged than the west side of Brúarjökull near Kverkfjöll. Again the dirt bands can be examined both in plan and in section. The section shown in Fig. I (p. 437) resembles in some respects the features to which Mr. Carruthers has drawn our attention. But again far the greater part of the cliff consists of ice. It is difficult to conceive that, as this ice melted out, the overthrusts and contortions would remain substantially in their original state. Yet certain of the convolutions in Mr. Carruthers's sections appear quite clearly defined even under a microscope. I should have thought it far more likely that at least some of the sections that Mr. Carruthers has examined show muds - possibly lake muds-which were subsequently contorted when they were frozen. The more we learn of conditions at the end of the Pleistocene the more definite is the evidence of frequent oscillations and this picture of climatic oscillation is being painted still more clearly for the last few centuries. ${ }^{5 a, b}$ It seems, therefore, that we must now accept frequent oscillations of an ice front as normal rather than exceptional. Such oscillations must have caused the lobes of the Pleistocene ice sheet to have over-ridden in very many places the deposits previously laid at their margins. Whatever the combination of cold and increased precipitation that combined to produce these advances may have been, it seems reasonable to assume that the same climatic changes would have caused the terrain bordering the ice to freeze. Where this terrain included lake sediments, especially if in the meantime the lake waters had been drained away, they may be expected to have frozen. This interpretation of certain of Mr. Carruthers's sections would overcome the great difficulty of envisaging little or no change in complicated little folds and overthrusts when the ice melted away. No doubt much besides this is involved in the interpretation of Mr. Carruthers's, sections, but one example of contortions very similar to many photographed by Mr. Carruthers, and which almost certainly originated from the folding of frozen muds and soil, will serve to illustrate my point.

Fig. 2 (p. 437) taken in 1937 shows an old vegetated moraine of Eyjabakkajökull. A lake is seen enclosed between this moraine and the debris-covered glacier tongue beyond. The simple Jura type of folds-gentle in the outermost arcs and steeper and higher in the inner ones-suggest that this moraine received a forward push by a re-advance of the glacier subsequent to the original building of the moraine. This re-advance is probably either that of $175^{\circ}-60$ or that of $184^{\circ}-5^{\circ}$, which have been well authenticated in Iceland by Thorarinsson. ${ }^{6}$

Fig. 3 (p. 437) is a close-up of a six-foot section dug into one of the folds. It shows well the nature of the distortions which developed as the whole mass was pushed towards the right by the advancing glacier. When examined closely the contortions were not as clear-cut as some of those described by Mr. Carruthers. The material consisted of alternate layers of white pummice sand from volcanic outbursts, black basaltic sand, grey clay, reddish-stained peaty layers, and so on. This material was much coarser than that in which Mr. Carruthers noted the very fine folds. Most of the bands therefore lacked the cohesion of fine clays. The disturbance caused by clearing the section made the sands trickle out in places. In spite of these differences the general resemblance to many of Mr. Carruthers's sections is remarkable, and suggests that the hypothesis of subsequent folding of frozen lake muds should not be too lightly cast aside.

\section{For references see next page.}

Professor N. E. Odell (Dept. of Geology, University of Otago, Dunedin, N.Z.): I came here as a mere listener and not as a qualified contributor. It has been most interesting to listen to Mr. Carruthers and others to-night, but not having seen the recent papers of the former speaker on the controversial question of his shear-clays and the like, I do not feel competent at the moment to discuss them. Mr. Lewis has just emphasized the exaggerated impression that one is apt to get of silt bands outcropping in the terminal front of a glacier. I can bear this out from some examples which I have seen in the fronts and the flanks particularly of certain Arctic glaciers. Differential 
movement along overlapping shear planes has been responsible in many cases for a greatly broadened extent of outcrop. During my last summer's work with the expedition of the Arctic Institute of North America (Project "Snow Cornice") in the St. Elias Range along the Yukon-Alaska boundary, the heavy snowfall of the previous winter $(c a .4 .6 \mathrm{~m}$.) masked, even towards the end of the summer, most of the glacial features of moraine and silt bands, which are known to be so spectacular in many of the great ice streams of this region. Observations of this kind were therefore limited, even during our extensive flights over the area.*

One interesting discovery (perhaps somewhat out of context here) which I made was of that peculiar and at present little-known life-form, the ice- or glacier-worm, which is a species of oligochaet. Details of this find are to be published in Nature. $\uparrow$ All that need be said at the moment is that we do not know either the life-history or the past history of ice-worms. Mr. Carruthers, however, tells me that in the minute sand-partings of his shear-clays are sometimes found what appear to be worm-trails. Whether these "trails" are of organic origin or not has yet to be demonstrated, but the phenomenon opens up a broad field of interest, glaciological and biological.

Professor W. B. R. KING, F.R.S. (communicated): I was most interested in the three contributions given by Professor Hollingworth, Mr. Carruthers and Mr. Lewis. Professor Hollingworth certainly brought forward evidence from his work on drumlins which does not fit in with Mr. Carruthers's views on the formation of Till. It was to be noticed that Mr. Carruthers did not attempt to answer Professor Hollingworth's points. In this I do not mean that I feel that Mr. Carruthers has not got strong evidence for some of his contentions. Particularly so is this the case for the underwashed surface of the Upper Tills. Certain sections which I have examined appear to me to be very difficult to interpret on any other theory than that the Till was in existence before the sands immediately underneath got into their present state. Each section must be considered on its merits and I do not feel that Mr. Carruthers has proved that a single glaciation for the origin of all the Tills of England is correct against the accumulated evidence of many other workers. Mr. Carruthers's theories regarding the origin of the laminated clay deposits should, if possible, be tested against the varve clay origin of these clays. In an area like the Vale of York, if these clays are formed from banded ice, it would not be expected that a pattern of varves similar to those described by de Geer would be discernable over a wide area. If on the other hand the bands can be correlated by their pattern over a fairly large area, surely they must be varves. Now that light boring apparatus which takes samples without disturbing the bedding is available, this could easily be put to the test.

I am sure we must thank Mr. Carruthers for making us look at these interesting deposits more closely and critically, and for bringing together so many lines of evidence.

* Glaciological investigations of the expedition on the Seward firn field, under Professor R. P. Sharp, will be reported in due course.

$\dagger$ Vol. 164, No. 4182, 1949, p. 1098.

\section{R E F E R E N C E S}

I. Roberts, B. B. The Cambridge Expedition to Vatnajökull r932. Geographical fournal, Vol. 81, No. 4, 1933, p. $289-313$ I. Roberts, B. B. The Camction of meltwater in cirque formation. Geographical Review, Vol. 30, No. 1, 1940, p. $64-83$. 2. Lewis, W. V. The function of meltwater in cirque forms Institute British Geographers, No. 13, 1947, p. 19-44.

3. - Valley steps and glacial valley erosion. Transactions Institute British Geographers, No. 13, 1947, p. 19. 1,1940, p. 24.

4. Dirt cones on the northern margins of Vatnajökull, Iceland. Fournal of Geomorphology, Vol. 3, No. 1, 169-9.

5. (a) Ahlmann, H. W. The present climatic fluctuation. Geographical fournal, Qol. Trterly Fournal Royal Meteorological Manley, G. Some recent contributions to
Society, Vol. 70, No. 305, 1944, p. 197-219.

6. Thorarinsson, S. Vatnajökull. Scientific results of the Swedish-Icelandic investigations 1936-37-38. Geografiska Annaler, Årg. 25, Ht. I-2, 1943, p. I-54. 
Fig. I. Dirt bands in the tongue of Eyjabakkajökull, east Iceland, showing faults and warping (see text p. 435)

Fig. 2. Fura-type folds in a vegetated moraine near the end of Eyjabakkajökull
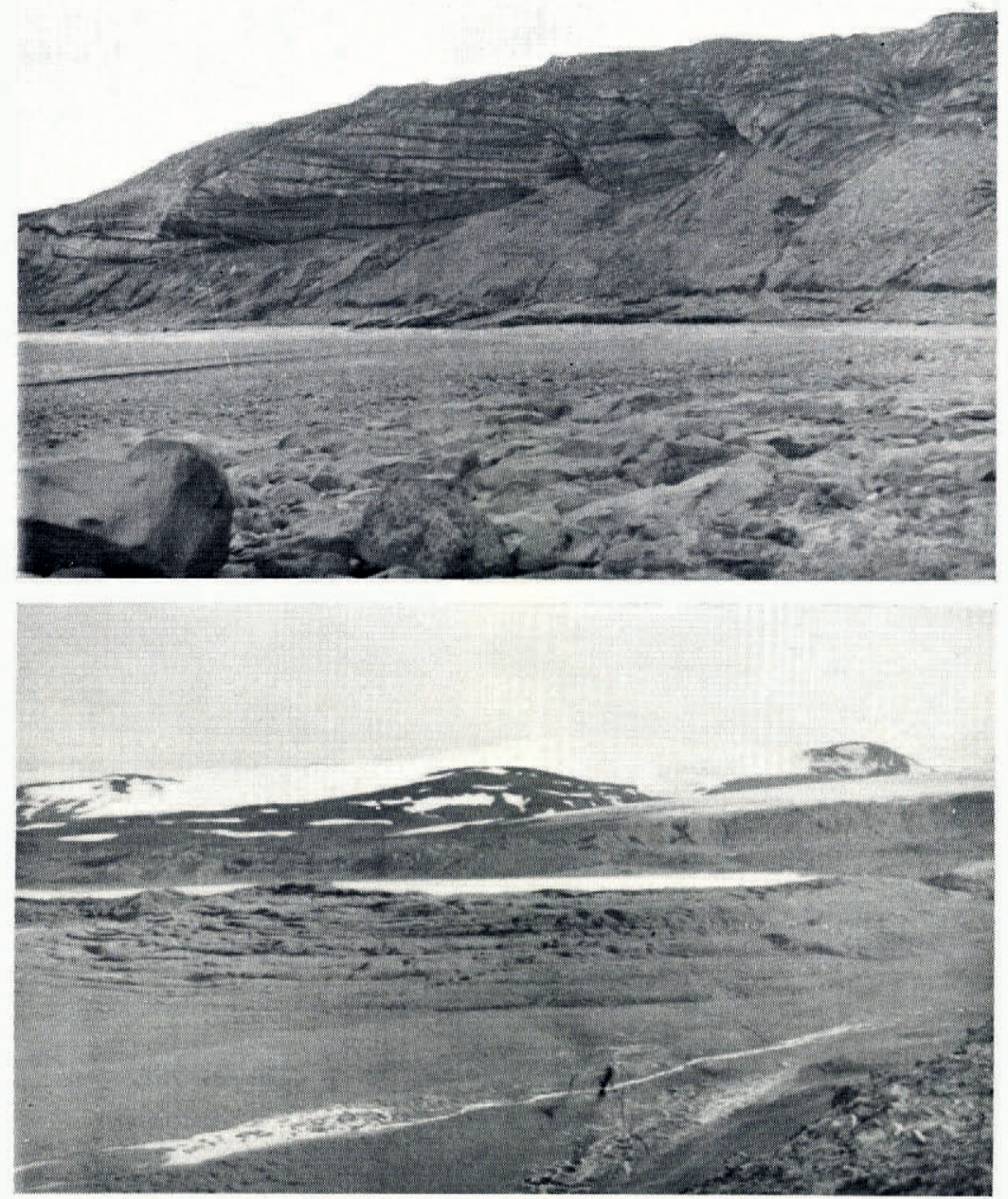

Fig. 3. Close-up of a transverse section cleared in one of the folds shown in fig. 2. The inch tape is 3 feet ( $9 I$ cm.) long

Photographs by $W$. V. Lewis

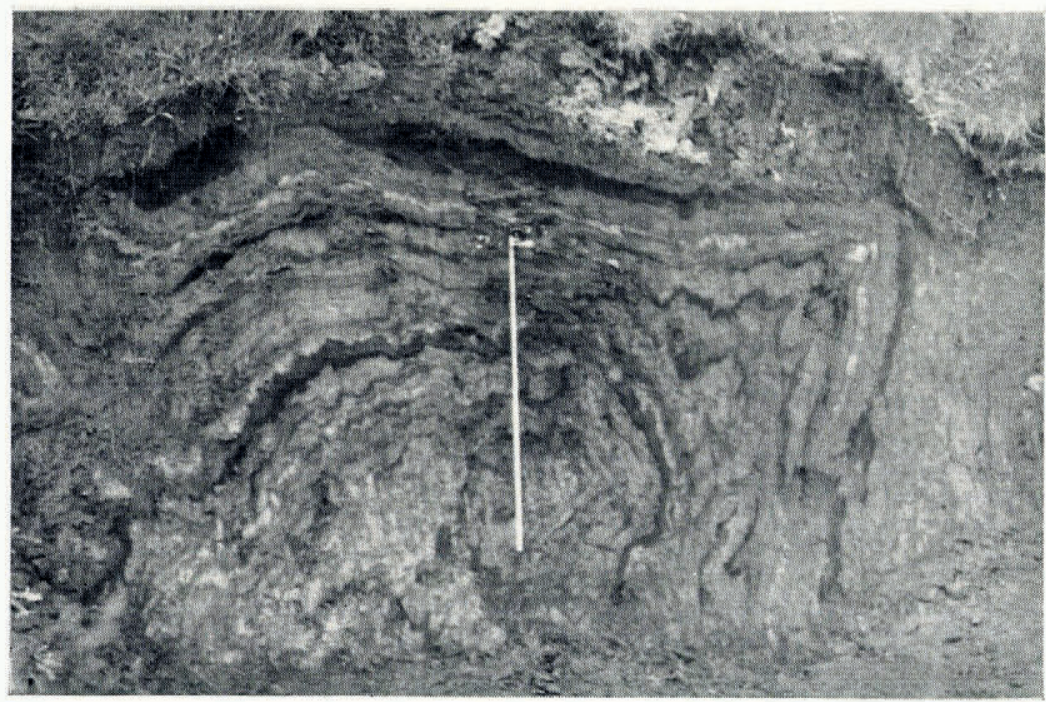




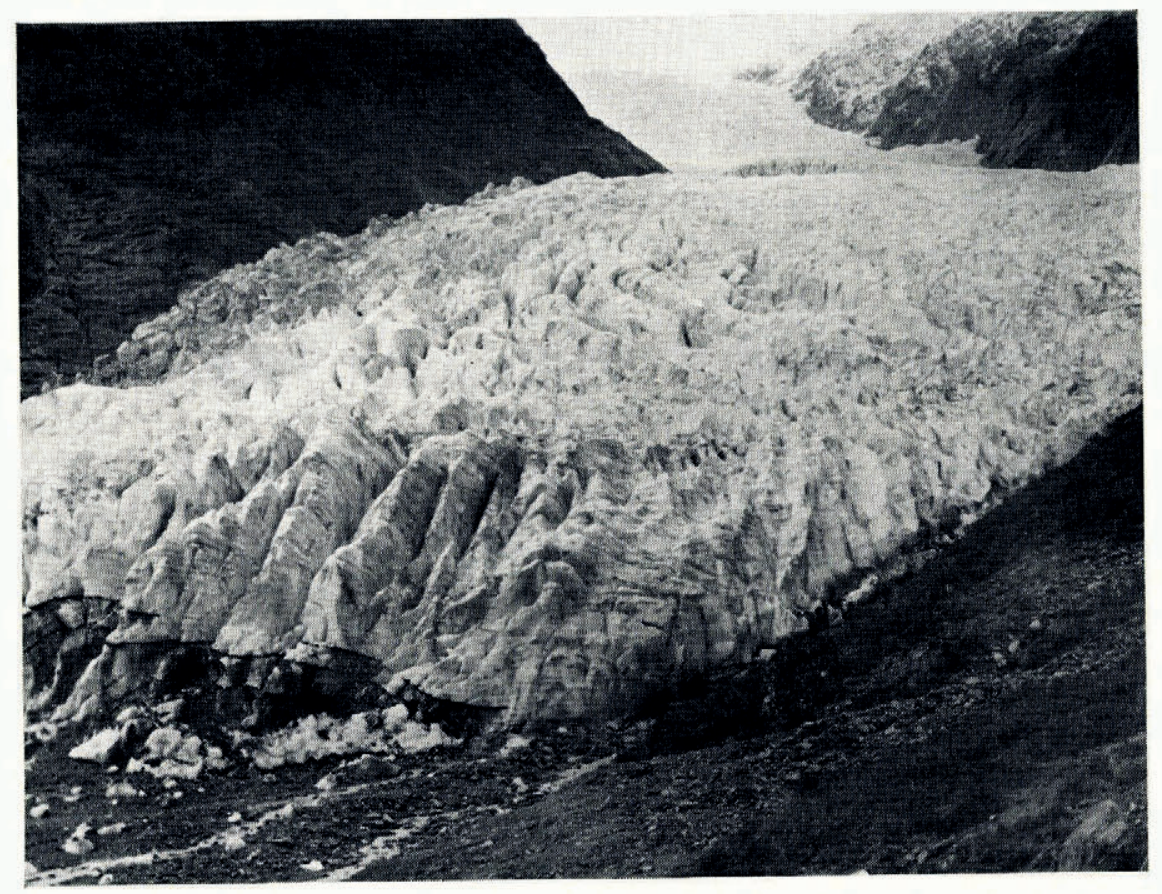

Fig. I. The snout of the Franz Fosef Glacier in October 1948 , showing overthrusting of the upper layers of the ice over the lower layers. (See text p. 426)

Fig. 2. A pillar of stratified sand originally filling $a$ vertical melt hole in the ice of Tverrabreen, Fotunheimen. (See letter p. 457)

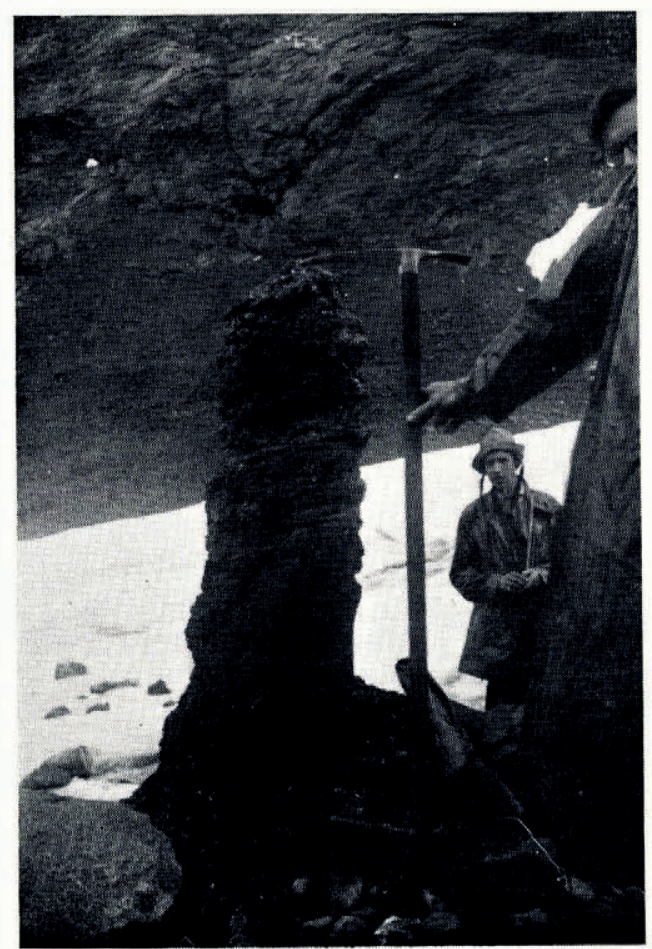

Fig. 3. Hr. O. Liestöl holding a $36 \mathrm{~cm}$. long ice crystal from the surface of Storbreen at an altitude of $1650 \mathrm{~m}$. (See text p. 467)

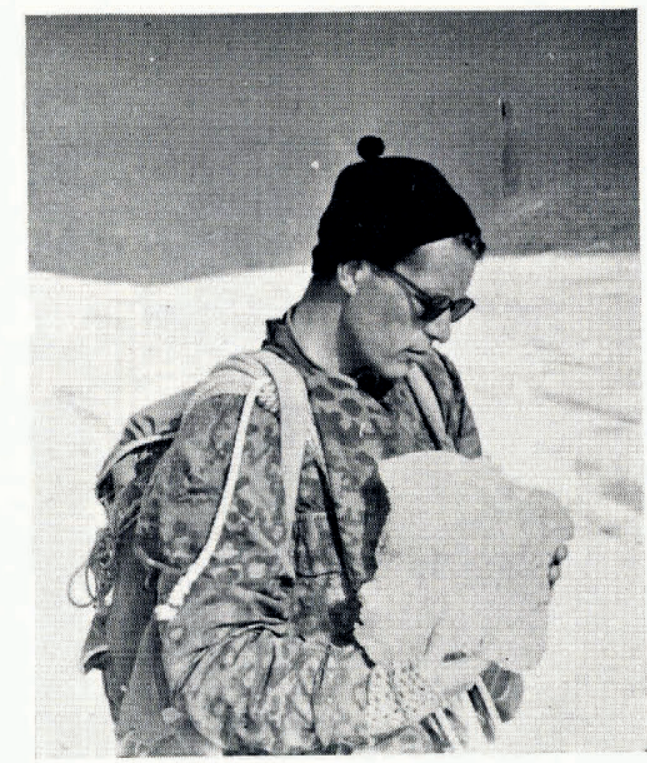

